\title{
Unexpectedly curved spines in a Cambrian trilobite: considerations on the spinosity in Kingaspidoides spinirecurvatus sp. nov. from the Anti-Atlas, Morocco, and related Cambrian ellipsocephaloids
}

\author{
Gerd Geyer ${ }^{1}$ (1) $\cdot$ Miguel Caldeira Pais ${ }^{2} \cdot$ Thomas Wotte $^{3}$
}

Received: 4 July 2019 / Accepted: 29 January 2020 / Published online: 25 February 2020

(c) The Author(s) 2020

\begin{abstract}
The new ellipsocephaloid trilobite species Kingaspidoides spinirecurvatus has a spectacular morphology because of a unique set of two long and anteriorly recurved spines on the occipital ring and the axial ring of thoracic segment 8 . Together with the long genal spines this whimsical dorsally directed spine arrangement is thought to act as a non-standard protective device against predators. This is illustrated by the body posture during different stages of enrolment, contrasting with the more sophisticated spinosities seen in later trilobites, which are discussed in brief. Kingaspidoides spinirecurvatus from the lower-middle Cambrian boundary interval of the eastern Anti-Atlas in Morocco has been known for about two decades, with specimens handled as precious objects on the fossil market. Similar, but far less spectacular, spine arrangements on the thoracic axial rings are known from other ellipsocephaloid trilobites from the Anti-Atlas of Morocco and the Franconian Forest region of Germany. This suggests that an experimental phase of spine development took place within the Kingaspidoides clade during the early-middle Cambrian boundary interval.
\end{abstract}

Keywords Cambrian $\cdot$ Trilobita $\cdot$ Systematics $\cdot$ Biostratigraphy $\cdot$ West Gondwana $\cdot$ Morocco

\section{Introduction}

The development of spines in trilobites reflects an evolutionary arms race over most of the Palaeozoic. This is particularly signposted by a palpable bloom of spiny trilobites from the late Silurian to the end of the Devonian. Spines are

Handling Editor: Joachim T. Haug.

Gerd Geyer

gerd.geyer@uni-wuerzburg.de

Miguel Caldeira Pais

mediterranean.world@gmail.com

Thomas Wotte

thomas.wotte@geo.tu-freiberg.de

1 Institut für Geographie und Geologie, Lehrstuhl für Geodynamik und Geomaterialforschung, Bayerische Julius-Maximilians-Universität Würzburg, Am Hubland, 97074 Würzburg, Germany

2 Mediterranic Store Lda., Praça Adriano Correia de Oliveira $\mathrm{n}^{\circ}$ 9, 7780-133 Castro Verde, Portugal

3 Institut für Geologie, TU Bergakademie Freiberg, Bernhard-von-Cotta-Straße 2, 09599 Freiberg, Germany present among the earliest trilobites at the base of Cambrian Stage 3, but these include genal spines and more or less pronounced pleural spines only (as in genera such as Eofallotaspis, Fallotaspis or Archaeaspis). All of these are best regarded as representing part of a beneficial cover by the dorsal exoskeleton in species that needed to perform a more or less distinct inclination of the body along the length axis to allow pronounced enrolment, in some species possibly combined with improved stability on a soft substrate. Early Cambrian trilobites generally retained such a "primordial" organization and spinosity. However, small to medium-sized spines on the occipital ring, axial rings or the lateral and posterior margins of the pygidium developed progressively, apparently as a response to environmental factors, and all of them were nearly upright to more or less gently rearwardly directed. It is generally accepted that new selective pressures from predators prompted animals to craft innovative protective devices, which in several species included longer and more strongly curved spines.

A simple evolutionary solution of enhanced protection was offered in amplifying structures that already existed in predecessors. This solution was frequently performed, but is often not an ideal answer to environmental stresses. 
Nevertheless, here we portray a new Cambrian trilobite species with characters of the genus Kingaspidoides, which was fairly common in the Cambrian continents West Gondwana and Baltica. However, this species, Kingaspidoides spinirecurvatus sp. nov., is easily distinguished from all other well-known species of its genus, and all other ellipsocephaloid trilobites known thus far, by having two long spines on the axis that curve anteriorly rather than rearwardly as in all other Cambrian trilobites known to date. Several specimens of Kingaspidoides are known that appear to indicate an experimental period in respect to the development of occipital and axial spines in the lower-middle Cambrian boundary beds in West Gondwana, with K. spinirecurvatus as an extreme form of a morphological experiment with regard to an apparently "wrong" direction of the curvature in the two extravagant spines.

\section{Trilobite spines as a bioconstructional system}

Spiny trilobites occur particularly frequently in Devonian strata of the Moroccan Anti-Atlas, with a number of species having spines curved in a way that is difficult to understand in terms of their functional morphology. One example for such spines that serve as an organized device is Koneprusia dahmani Chatterton, Fortey, Brett, Gibb and McKellar, 2006, which has rearwardly curved genal and occipital spines as well as long dorsally directed spines on the axial rings, but also extended pleural spines which are distinctly curved towards the axis rather than in a rearward direction. However, this entire set of spines forms a spiny cage, which unmistakably was aimed at repelling attacks of possible aggressors (Fig. 1a-c). A similar strategy can be postulated for the quite different spine apparatus developed in Dicranurus monstrosus (Barrande, 1852). This species is equipped with a pair of almost spirally coiled occipital spines, as well as abaxially directed genal spines and pleural spines pointing in different directions, but progressively rearward in the posterior thoracic segments.

A special case of axial spine armour is developed in such species as Psychopyge praestans Morzadec, 2001 and $P$. hammerorum Chatterton, Fortey, Brett, Gibb and McKellar, 2006. Well preserved specimens of these species show that not all axial rings bear distinct spines (Chatterton et al. 2006, pl. 24, figs. 2, 3). Axial rings with long rearwardly directed spines are separated by two or even three segments lacking axial spines. In addition, a conspicuously rearwardly curved occipital spine is followed by three non-spinose axial rings, and segment 4 with only a relatively small axial spine that corresponds spatially with the tip of the occipital spine (Fig. 2a, b).
More stunning, however, are trilobites with few, but well developed, spines that apparently cannot be considered as a near-optimal solution for a defensive strategy (as shown for Koneprusia, above) and are far from forming an apparatus. Such morphotypes include numerous species of Cyphaspis, such as C. smeenki Van Viersen and Holland, 2016, C. heisingi Van Viersen and Holland, 2016, C. ihmadii Van Viersen and Holland, 2016, and C. eberhardiei Chatterton, Fortey, Brett, Gibb and McKellar, 2006, all with only two long genal spines and a single long, curved axial spine on segment 6 or 7, respectively (e.g., Fig. 1d-f). With 12-14 thoracic segments in total, these species are reminiscent of the morphology of the Cambrian species Kingaspidoides spinirecurvatus described herein.

\section{Spinosity in Kingaspidoides spinirecurvatus and other species of the Kingaspidoides clade}

Kingaspidoides spinirecurvatus sp. nov. is characterized by a long occipital spine and a long axial spine on segment 7 or 8 , both of ca. two-thirds the cephalic length or up to cephalic length, and both being curved anteriorly. The occipital spine is usually slightly less curved and generally describes an arc of roughly one-third of a circle, the axial spine is usually slightly more strongly bent and describes an arc in the order of 40 percent of a circle. On a stretched-out individual, these spines are generally subvertically oriented (Figs. 3a, $4 \mathrm{a}-\mathrm{c}$, $\mathrm{i}, 8,9 \mathrm{f}-\mathrm{i}$ ). They do not suggest an obvious purpose because the distance between them and their positions on the exoskeleton appear to be unsuitable for an effective protective function. However, $K$. spinirecurvatus is frequently found in various types of enrolment, ranging from specimens with the cephalon slightly inclined against the thorax to specimens with (in lateral view) a concave curvature of the thorax to a near-spherical enrolment (Figs. 3c, 4d-h, j, 9a-e). In these inclined or enrolled postures, it becomes obvious that the long extended genal spines play a role in the functional significance of the spine apparatus. The three exemplary postures depicted in Fig. 3 illustrate strongly differing situations for the spatial relations of these prominent spines.

If the cephalon is inclined at $20^{\circ}$ and more against the thorax, the tips of the genal spines reach back to the level of the macrospinose segments 7 or 8 and form a lateral barrier in the anterior part of the thorax (Fig. 3a). The efficacy of this lateral protective structure is slightly enhanced by a notable adaxial curvature of the genal spines' distal portions.

A concave curvature of the trilobite body is commonly believed to represent a resting stage (e.g., Seilacher 1959; Bergström 1983; Figs. 3b, 8). Rusophycus-type traces result from this situation during the lifetime of the animals and provide evidence for short-distance burrowing activities. 


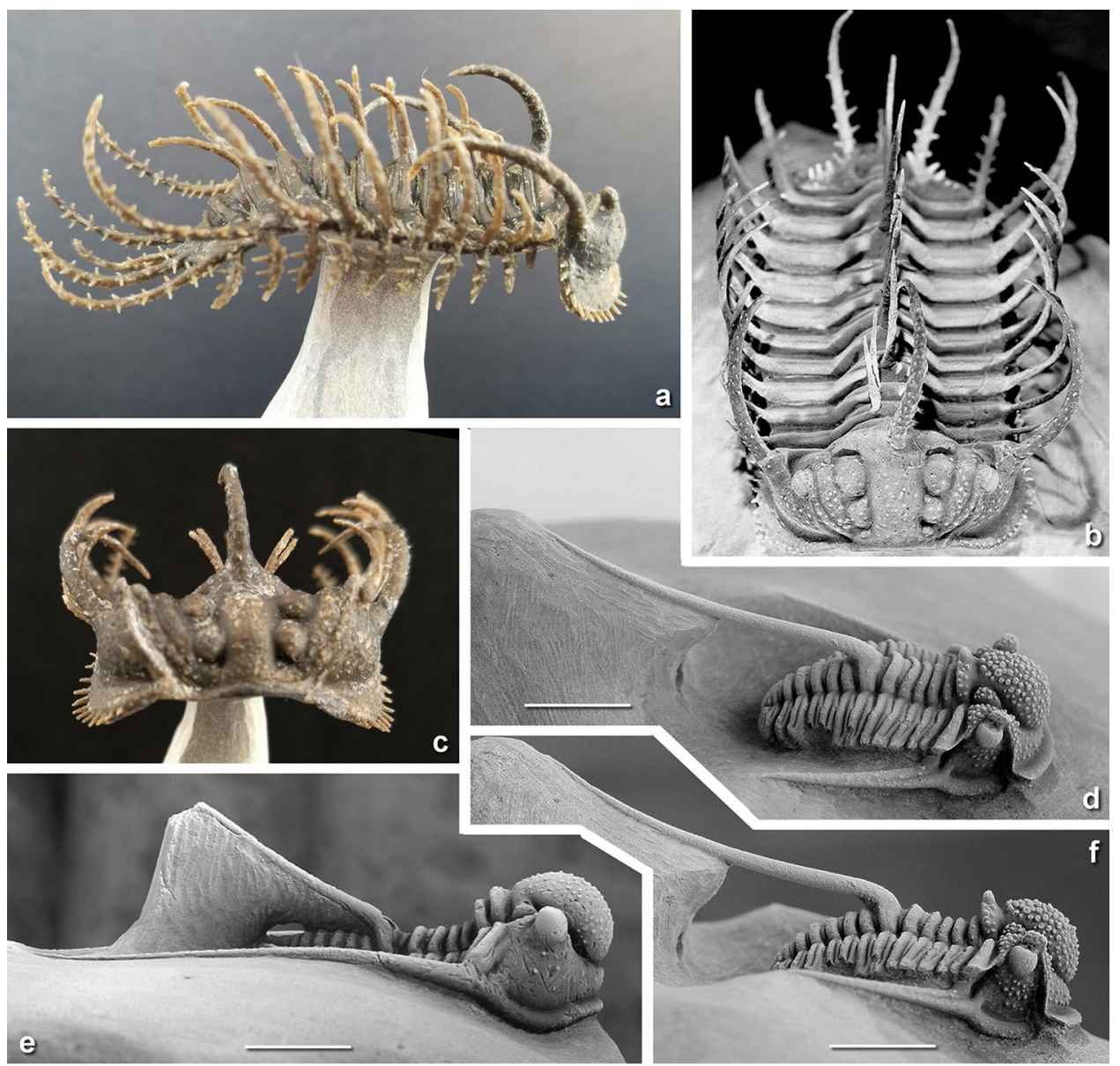

Fig. 1 Spine apparatuses in Devonian trilobites. a-c Koneprusia dahmani Chatterton, Fortey, Brett, Gibb and McKellar, 2006. a, b Dorsal exoskeleton, lateral and anterior views; Timrhanrhart Formation, upper Emsian, Devonian, Oufaten, Anti-Atlas, Morocco. c Holotype, UA13428, oblique anterodorsal view showing differences in spine arrangement between anterior and mid to posterior thoracic segments; Timrhanrhart Formation, upper Emsian, Devonian, northeast of Jbel Gara el Zguilma, Anti-Atlas, Morocco. d, f Cyphaspis heisingi Van Viersen and Holland, 2016, holotype, IRSNB a13011,

In $K$. spinirecurvatus, this posture of the body moves the occipital spine back, with its terminal part being directed more perpendicularly to the length axis. The long axial spine with its pronounced curvature, in contrast, is moved forward so that its tip approaches the rearwardly inclined occipital spine. The genal spines are directed posterodorsally and cannot be deemed helpful for protection in this situation.

In a strongly enrolled position, each thoracic segment is inclined at an angle similar to that of its neighbouring segments, whereas the anterior thoracic segments are inclined at a higher angle to the cephalon. Due to the relatively large cephalon, the animals were not able to perform a complete spherical enrolment, and near-completely enrolled specimens are very rare. One specimen that comes close to the maximum enrolment of the species is known and provides nearly complete dorsal carapace, Assa Formation, Pragian, Mdâour el Kbîr, Anti-Atlas, Morocco; oblique lateral and lateral views illustrating the position and direction of macrospine on thoracic segment 6 . $\mathrm{e}$ Cyphaspis ihmadii Van Viersen and Holland, 2016, holotype, IRSNB a13021, nearly complete dorsal carapace, Bou Dîb Formation, Givetian, Issoumour 2 section, Anti-Atlas, Morocco; lateral view illustrating the position and direction of macrospine on thoracic segment 6 . All scale bars $5 \mathrm{~mm}$ (From Chatterton et al. 2006, pl. 53, fig. 7, reproduced with permission)

insight into the direction of the spines and the positions of their tips in that posture (Fig. $4 \mathrm{~d}, \mathrm{e}, \mathrm{h}, \mathrm{j}$ ). In this case, the occipital spine, the genal spines, and the macro-axial spine present different angles with respect to the various axes. However, if the centre of the enrolled body is taken as a reference point, the tips of the spines form (in lateral view) a series separated by similar angles of $70-80^{\circ}$ from each other. The spaces between the resulting equidistant positions of the spines are smaller than the average size of supposed predators from this interval in the Cambrian so that this posture could act as a simple barrier. This appears to be the best possible mechanical solution of a defensive structure against a large predator, being composed solely of four spines, and being based on parsimonious, economic material input with few adaptive characters. 

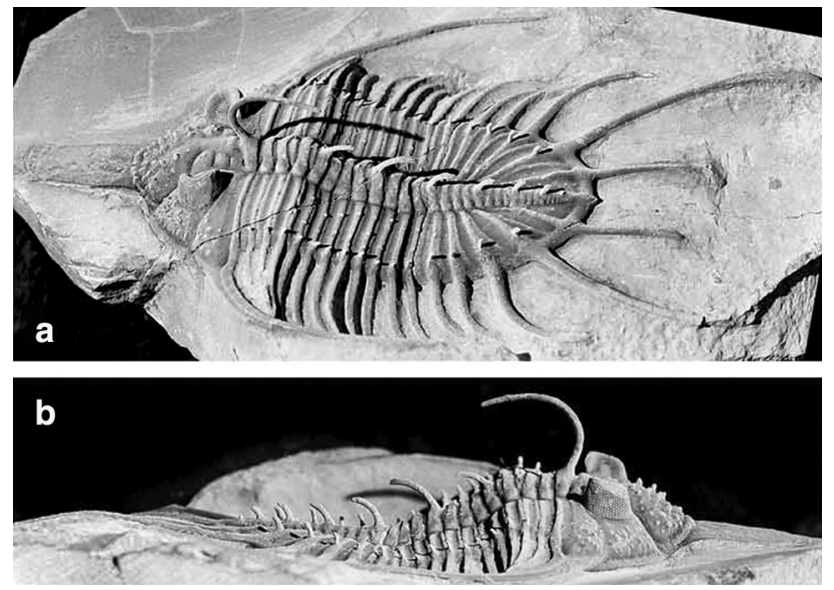

Fig. 2 Psychopyge praestans Morzadec, 2001, UA13369, nearly complete dorsal exoskeleton, oblique lateral (a) and lateral (b) views illustrating rhythmic differentiation of axial spines on the thorax. Supposedly topotypic specimen from Timrhanrhart Formation, upper Emsian, Devonian, northeast of Jbel Gara el Zguilma, Anti-Atlas, Morocco (From Chatterton et al., 2006, pl. 22, figs. 2, 3, reproduced with permission)

It needs to be emphasized that another specimen of Kingaspidoides spinirecurvatus shows a modified version of post-mortem configuration in which the small pygidium forms a flap underneath the posterior thoracic segments (Fig. 9i). Such a configuration is known from several other ellipsocephaloids (see an example of Hamatolenus (Myopsolenus) magnus (Hupé, 1953) in Geyer 1990, pl. 44, fig. 12; similarly known from Ellipsocephalus hoffii (Schlotheim, 1823) from the Wuliuan of Bohemia).

In conclusion, the presence of two anteriorly curving long spines on the occipital ring and on a posterior thoracic segment, in combination with long, straight (in lateral aspect) genal spines provide a solution for a simple protective system that works under different situations of inclination of the body, in trilobites with a relatively low number of thoracic segments and a small pygidium. The curvature of the occipital spine has to be forward to enable a considerable concave curvature of the thorax to have the spine directed dorsally. The curvature of the axial spine is necessary to maintain a protective device during strong enrolment.

That the morphology of Kingaspidoides spinirecurvatus is a possible and extreme response to supposed predatorial stress can be deduced from additional species/forms of Kingaspidoides and related genera in the Jbel Wawrmast Formation of the Moroccan Anti-Atlas. The period of deposition of this formation obviously formed a temporal and spatial playground for different morphological experiments. Most of the common species of Kingaspidoides do not have long genal, occipital, or axial spines. Such a typical morphology is developed in Kingaspidoides angustigena (Geyer, 1990) and Cambrosaurura usitata (Geyer, 1990) from the Morocconus notabilis Biozone of the Jbel Ougnate region of Morocco, with only relatively short genal spines, a small occipital node, and minute axial nodes, which grow in size in segments 7-9 or 10. Sometimes these nodes are extended into minute spines that cause the axial rings to break off when the rock is split (Fig. 5e). Rare findings show that Kingaspidoides angustigena had a single medium-sized axial spine on thoracic segment 8 (Fig. 5a, b, d), at apparently the same position as the long axial spine in $K$. spinirecurvatus, in addition to the medium-sized or long occipital spine that is more often preserved (Geyer, 1990, pl. 31, figs. 5, 8). One example of character alteration is shown by extremely diverging and broadened genal spines in Kingaspidoides sp. A (Fig. 5c, f) which could be considered as an adaptation to fine-grained and very soft substrate. However, the specimens of this species are found in rocks that do not indicate a pronounced soupy substrate present during deposition.

Although the morphologies of the cranidium in Kingaspidoides spp. and closely related genera such as

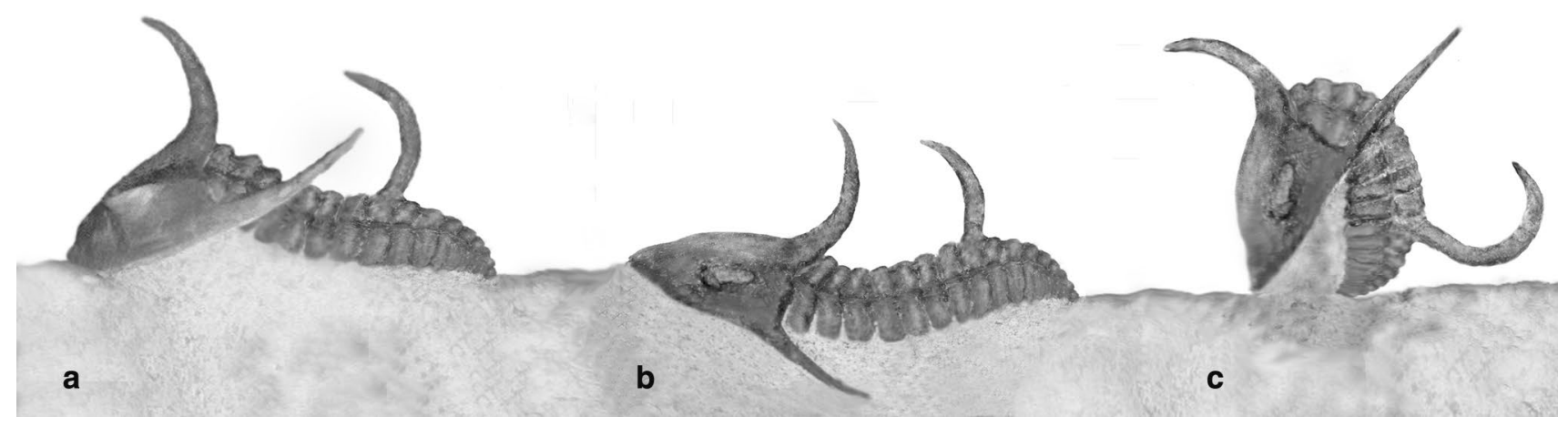

Fig. 3 Kingaspidoides spinirecurvatus sp. nov. Reconstruction of spine positions and directions during different modes of inclination of dorsal exoskeleton. a Lateral view of body during moderate inclination of cephalon in respect to thoracopygon. b Lateral view of body during double curvature of thorax along longitudinal axis. c lateral view of body during nearly complete enrolment. Explanations in the text 
Ornamentaspis, Cambrosaurura, and Kingaspis are often difficult to distinguish at the species level, the thoraces of the species often show pronounced differences (see Cederström et al., under review). Similar thoracic characters occur in several combinations in different genera, which indicates a mosaic pattern induced by rapid diversification in the ellipsocephaloid clade as suggested earlier (Geyer 1990, 2017). These differences in thoracic character have not been discussed in detail for the group, but some remarks are presented in Cederström et al. (under review).

Among these forms with different patterns of occipital, genal, and thoracic axial spines is a single specimen of a new species from probably the same carbonate bed as Kingaspidoides spinirecurvatus of the Jbel Ougnate region of Morocco with a spine pattern that offers an explanation for the evolutionary development of the spinosity towards K. spinirecurvatus. This specimen (Fig. 6a-d), similar to $K$. spinirecurvatus in most morphological characters, has a moderately long, rearwardly directed and slightly curved occipital spine and nearly straight axial spines of different lengths on segments 4-6 and probably 7 . It appears as if their lengths grow from segment 4 to 6 and then diminish. An additional axial spine of considerable strength and length is developed on thoracic segment 9 , which points strongly rearward in partly enrolled carapaces (Fig. 6c).

A similar configuration is seen in another form of Kingaspidoides from coeval strata in the Franconian Forest region, Germany. One specimen of this form shows the presence of a slightly curved, moderately long occipital spine, the absence of spines on thoracic segments 1 and 2, and the presence of strongly developed axial spines on segments $3-8$, with growing length from 3 to 5 and slightly decreasing in length in segments 5 through 8 (Fig. 6f). A very similar form exists in the Bréche à Micmacca Member (Morocconus notabilis Biozone) of the Jbel Ougnate region. It has moderately long, slightly curved axial spine on segments 3-6, but lacks spines on segments 1,2 and in the posterior third of the thorax (segments 7-11) (Fig. 5g, h).

Cambrosaurura robusta Geyer in Cederström et al., under review from the Bréche à Micmacca Member of the Jbel Ougnate area has a thick, moderately long and obliquely rearwardly directed occipital spine, but lacks distinct spines on the thoracic axial rings. Nevertheless, the axial rings of some of the thoracic segments show bulbous protuberances resembling short spines. The size of these nodes differs from segment to segment, reaching the maximum size in segments 7 through 9 (Fig. 6e), resembling the series of short spines seen in Kingaspidoides sp. B (Fig. 5g, h) and particularly Kingaspidoides sp. D (Fig. 6f).

A new, undescribed species of Kingaspis from the Jbel Wawrmast Formation of the Jbel Ougnate region is known only from sparse material and a single more or less complete dorsal exoskeleton (Fig. 6g). It has a long occipital spine and an exceedingly long axial spine on thoracic segment 6 , the tip of which reaches back to well posterior to the rear end of the pygidium. No other spines are developed in the thoracic axial rings, but the genal spines are also of considerable length. This configuration of spines is reminiscent to that known from some species of Cyphaspis. It suggests a similar protective strategy although Kingaspis sp. has a distinctly larger body size.

In summary, these different arrangements of axial spines on the thoracic segments indicate less spectacular arrangements apparently developed as protective devices against predatorial stress. They appear to indicate an experimental phase within the Kingaspidoides clade during the early-middle Cambrian boundary interval.

\section{Locality information, stratigraphical occurrence, and taphonomy}

The localities/areas from which the commercially traded specimens are originating is generally kept confidential. The specimens are collected from two different areas. The main excavating site lies near the western margin of Jbel Ougnate, eastern Anti-Atlas, in the vicinity of Jbel Ba Haddou near Tizi n'Tfarkhin, approximately at $31^{\circ} 18.5^{\prime} \mathrm{N} 5^{\circ} 16^{\prime}$ W (Fig. 7), and most of the specimens on the fossil market with slightly scratched surfaces seem to originate from this area. A second site with quarries exists near Tizi n'Izem, approximately at $31^{\circ} 30.5^{\prime} \mathrm{N} 4^{\circ} 50.0^{\prime} \mathrm{W}$, near the northern edge of Jbel Ougnate.

The strata in which the specimens occur comprise an interval that belongs to the regional upper part of the Bréche à Micmacca Member which forms the lower part of the Jbel Wawrmast Formation (Geyer 1989; Geyer and Landing 2006; Fig. 7). Due to regional differences in subsidence, the Bréche à Micmacca Member is particularly thickly developed in the Jbel Ougnate area, which in turn has provided favourable conditions for fossilization. This led to the establishment of several quarries in which Cambrian trilobites are recovered for commercial use, such as near Tarhoucht (Geyer 1993; Geyer and Vincent 2015), near Assemame (Devaere et al. 2014), or near Tizi n'Tfarkhin. However, these quarries are established in the lower and middle part of the Bréche à Micmacca Member, which belongs to the Morocconus notabilis Biozone. This part of the succession is rich in large specimens of Acadoparadoxides species (such as A. briareus and A. levisettii) as well as species of Hamatolenus (such as H. vincenti and H. marocanus) (Geyer 1993; Geyer and Vincent 2015; Geyer et al. 2019), which are frequent objects on the fossil market. The fossils from these strata are characterized by the ochre or red-brown colour of the objects on a yellow sandstone matrix due to the shell substance being largely leached. In contrast, trilobite 


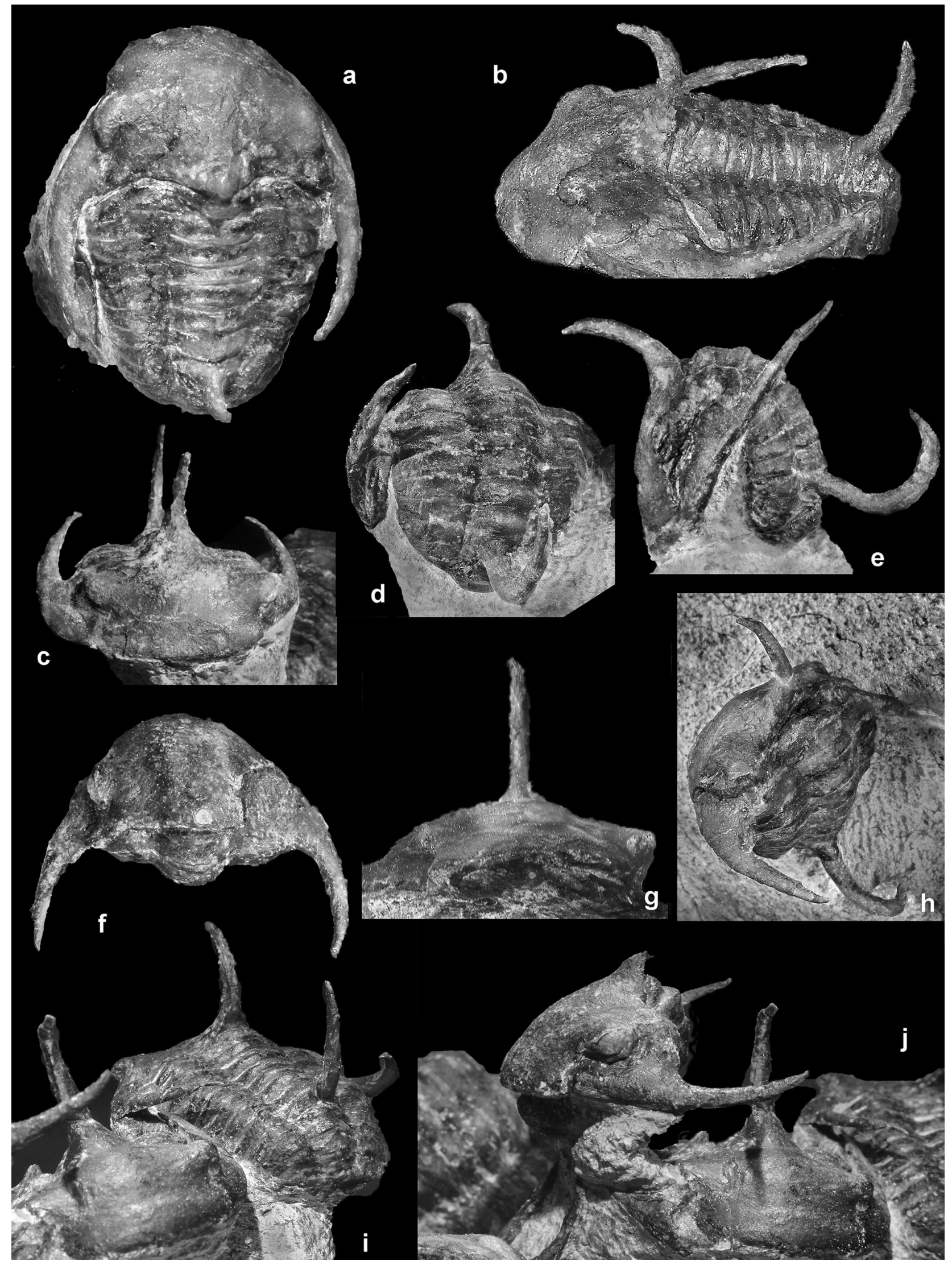


४Fig. 4 Kingaspidoides spinirecurvatus sp. nov., paratypes, cluster of at least eight specimens prepared from a single slab, with sizes ranging from ca. 27-36 mm length of an outstretched dorsal carapace. a-c BOM 1152a, complete dorsal exoskeleton, dorsal, oblique lateral and anterior views. d, e, h BOM 1152c, enrolled dorsal exoskeleton, oblique posterodorsal, lateral and oblique lateral views. $\mathbf{f}$ BOM 1152d, enrolled dorsal exoskeleton, dorsal view of cephalon. $\mathbf{g}$ BOM 1152f, incomplete dorsal exoskeleton, anterior view of cephalon. i BOM 1152d, 1152a, 1152b, and 1152e, dorsal exoskeletons. From Ornamentaspis frequens Biozone, Jbel Wawrmast Formation, upper Bréche à Micmacca Member, Jbel Ougnate region, eastern Anti-Atlas, Morocco, most probably from sample locality near Tizi n'Tfarkhin

specimens from the upper part of the Bréche à Micmacca Member in general and of Kingaspidoides spinirecurvatus in particular, are preserved in thin limestone beds with the cuticle preserved as black phosphatized shell. This part of the member belongs to the Ornamentaspis frequens Biozone although the boundary to the underlying $M$. notabilis Biozone is difficult to determine with certainty and does not correlate with the change in preservation.

The limestone beds of the upper part of the Bréche à Micmacca Member that bear the specimens are typical for the carbonate layers that mark the top of shallowing upward cycles and characterize a maximum flooding interval (see detailed explanations in Heldmaier 1998, and explanation for the lower part of the Bréche à Micmacca Member in Geyer and Vincent 2015), with some of the beds overgrown by microbial mats. These uppermost Bréche à Micmacca Member carbonates are usually developed as medium-grey shell hash beds with packstone to wackestone signature, which yield either complete, or more often fragmented, trilobite sclerites, but also brachiopod shells and several other fossil remains such as hyoliths, helcionelloids, and echinoderm ossicles (Geyer et al. 1995). Others are completely devoid of fossils. The trilobite, brachiopod, and hyolith sclerites in the lower beds are secondarily phosphatized in a style that allowed preservation of fine details on the surfaces, whereas the phosphatization leads to homogeneous layers without preservation of internal details of the cuticle and shell, respectively. However, in the Tizi n'Tfarkhin area and several other localities, the trilobites in the limestone beds frequently represent complete exoskeletons. A particularly spectacular assemblage of at least seven exoskeletons or sclerites which are mostly enrolled is present in the Bommel collection (Fig. 4). Detailed analysis of the specimens has revealed that they are indeed a carefully prepared natural assemblage and not artificially combined.

\section{Systematic palaeontology}

The material used in this study is reposited in the collections of the TU Bergakademie Freiberg (FG), the Naturmuseum Senckenberg, Frankfurt a. M. (SMF), the collection of Bommel, Bize-le-Minervois (BOM), the collection of Gérard Barbe, Reims (CGB), the collections of the Department of Earth and Atmospheric Sciences, University of Alberta, Edmonton (UA), and the Institut royal des Sciences naturelles de Belgique (IRSNB), respectively, under the listed collection number.

'Class' Trilobita Walch, 1771

'Order' Redlichiida Richter, 1932

'Superfamily' Ellipsocephalacea Matthew, 1887

'Family' Ellipsocephalidae Matthew, 1887

'Subfamily' Ellipsocephalinae Matthew, 1887

‘Genus’ Kingaspidoides Hupé, 1953, emend. Geyer, 1990

Type species. Kingaspis (Kingaspidoides) armatus Hupé, 1953 (=Kingaspis (Kingaspis) brevifrons Hupé, 1953).

Discussion. Kingaspidoides is among the ellipsocephaline genera which are difficult to differentiate from morphologically similar genera of the clade. The genus has been discussed in detail by Geyer (1990), with an update by Cederström et al. (under review).

As emphasized by Cederström et al. (under review), Kingaspidoides is characterized by a distinct reduction of the glabellar and genal convexity toward a Kingaspis-like aspect of the dorsal surface of the cephalic cuticle, whereas internal moulds show distinct axial furrows, well defined glabellar frontal margins and fixigenae which are domed independently from the glabellar convexity. Despite the numerous specimens of Kingaspidoides species known from the Moroccan Atlas ranges, well preserved pygidia were unknown from the Moroccan material. Well preserved pygidia of Kingaspidoides are known from Kingaspidoides frankenwaldensis (Wurm, 1925) from the Franconian Forest, Germany (Geyer 2017) and particularly from the Scanian $K$. nordenskioeldi (Linnarsson, 1883). These pygidia reconfirm the volucent type of pygidial morphology.

The similar genus Ornamentaspis has an analogous cranidial morphology on internal moulds, but shows a morphology of the exterior of the cuticle with a well demarcated glabella with a subtriangular anterior margin of the frontal lobe and fixigenae with a convexity independent from that of the glabella. In addition, the glabella has anterolateral corners without recognizable extensions into the eye ridges on the exterior. The palpebral lobes of Ornamentaspis are subevenly curved and form an arc subparallel to the elongated rise 


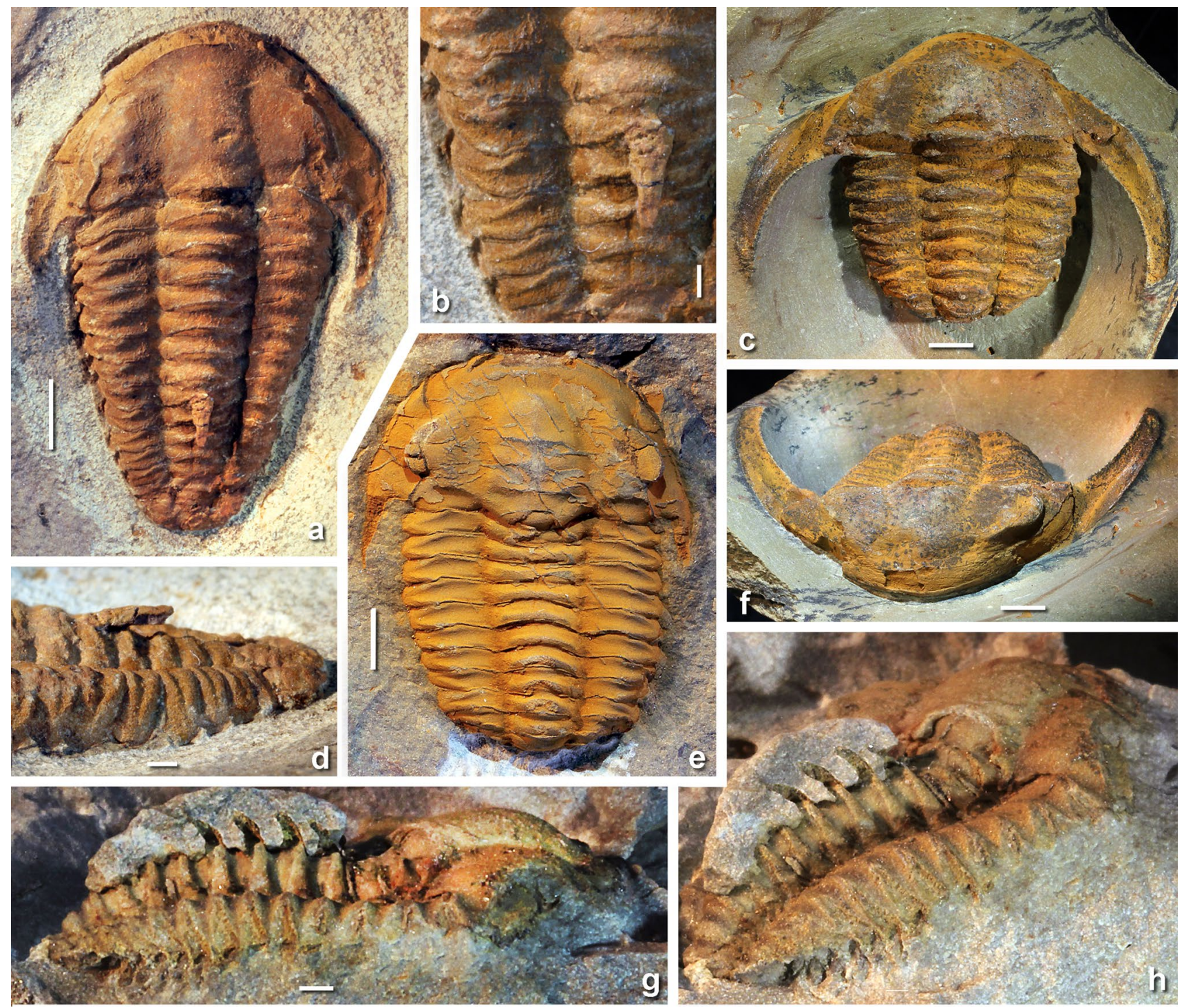

Fig. 5 a, b, d Kingaspidoides angustigena (Geyer, 1990), BOM 1543, nearly complete dorsal exoskeleton with slightly detached librigenae; a dorsal view; b, d dorsal and lateral view of middle and posterior parts of the thorax showing moderately large axial spine on thoracic segment 8 ; note short and mostly split-off posterior parts of axial rings in thoracic segments 1 through 7, suggesting a considerable ability for concave flexure in this part of the thorax; Morocconus notabilis Zone, Jbel Wawrmast Formation, Bréche à Micmacca Member, Jbel Ougnate region, eastern Anti-Atlas, Morocco, probably from near Tarhoucht. c, f Kingaspidoides sp. A, BOM 1430, nearly complete dorsal exoskeleton with slightly detached librigenae, partially enrolled, dorsal (c) and oblique anterior views; note broadened and obliquely abaxially directed genal spines; Morocconus notabilis Biozone, Jbel Wawrmast Formation, Bréche à Micmacca Member, Jbel Ougnate region, eastern Anti-Atlas, Morocco, probably from near Tarhoucht. e Kingaspidoides cf. laetus (Geyer, 1990), BOM 1436,

that forms the most elevated part of the fixigena, whereas the palpebral lobe in Kingaspidoides forms a torus-shaped bar with an elevation independent from the fixigenal morphology, so that the palpebral lobe in Kingaspidoides may nearly complete dorsal exoskeleton with posterior thoracic segments and pygidium ventrally curved, dorsal view; librigenae with relatively short and slender genal spines; axial rings of anterior thoracic segments 1-4 narrow to allow concave flexure of the carapace in this region, axial rings of thoracic segments 7-9 with axial node (mostly broken off); Morocconus notabilis Biozone, Jbel Wawrmast Formation, Bréche à Micmacca Member, Jbel Ougnate region, eastern Anti-Atlas, Morocco, probably from near Tarhoucht. g, h Kingaspidoides sp. B, BOM 1726, nearly complete dorsal exoskeleton, lateral and oblique posterolateral views showing moderately long, dorsally directed axial spines on thoracic segments 2 through 5, whereas spines are not developed on the axial rings posterior to segment 5; probably from Morocconus notabilis Zone, Jbel Wawrmast Formation, Bréche à Micmacca Member, from Anti-Atlas, Morocco, most probably from Jbel Ougnate region. All scale bars $5 \mathrm{~mm}$

be curved or almost straight. The palpebral furrow in Kingaspidoides is thus not evenly curved as in Ornamentaspis and frequently shows a nearly straight adaxial margin. On internal moulds of Ornamentaspis it proceeds into well 
recognizable depressions which separate the palpebral lobes from the eye ridges, whereas such a depression is less well developed in Kingaspidoides.

Latikingaspis Geyer, 1990 (type species Kingaspis (Kingaspis) alatus Hupé, 1953) differs from both Kingaspidoides and Ornamentaspis primarily in having broad axial furrows and librigenae and a relatively slender glabella. Its palpebral lobes have the characters seen in the species of Kingaspidoides, but are slightly shorter. The frontal region of the cranidium in Latikingaspis consists of an amalgamated unit of the anterior border and the pre-glabellar field/preocular areas, but is shorter than in Kingaspidoides.

Other genera of the Ellipsocephalinae are more easily differentiated from Kingaspidoides. Ellipsocephalus Zenker, 1833 , for example, can be distinguished, amongst other features, by its narrow pre-glabellar field and the correspondingly longer glabella, shorter and less convex palpebral lobes, librigenae without a genal spine, and particularly by its transversely narrow, sublenticular pygidium with a relatively indistinctly defined axis. Kingaspidoides, in contrast, has librigenae with distinct genal spines and a volucent/ subcordate pygidium with a well-defined, longitudinally elongate axis.

The differences between Kingaspidoides and other genera of the Ellipsocephalinae (such as Germaropyge Šnajdr, 1957, Ellipsostrenua Kautsky, 1945, Kingaspis Kobayashi, 1935, Mesetaia Hupé, 1953, Kymataspis Geyer, 1990, Planolimbus Geyer, 1990, Elatius Orłowski, 1985, or Cambrosaurura Geyer in Cederström et al. (under review) are discussed in detail in Cederström et al. (under review).

\section{Kingaspidoides spinirecurvatus sp. nov.}

Figures 3, 4, 8, 9

Holotype. TU Bergakademie Freiberg collection FG 688.

Type locality. Near Tizi n'Tfarkhin, western Jbel Ougnate, eastern Anti-Atlas, Morocco.

Type stratum. Jbel Wawrmast Formation, upper part of Bréche à Micmacca Member; Ornamentaspis frequens Biozone.

Paratypes. Collection Patrick Bommel, BOM 1153, seven more or less complete dorsal exoskeletons. Collection Gérard Barbe, CGB T. 41, complete dorsal exoskeleton. Collection Devoille, DEV C 15.2b.

Diagnosis. Species of Kingaspidoides with moderately elevated glabella of ca. $80 \%$ cephalic length (except occipital spine) and $35-40 \%$ cranidial width across centre of palpebral lobes, frontal lobe of glabella with indistinct arcuation of anterior margin; lateral glabellar furrows S1 through
S4 indistinct on the exterior of the cuticle; occipital ring extended into a long and dorsally curved spine; palpebral lobes relatively short (ca. one-quarter cephalic length), poorly defined from fixigenae on the exterior of the cuticle; anterior area convex on sagittal line, strongly deflected ventrally; anterior border furrow obsolescent. Thorax of adult individuals composed of ca. 14 segments; axial rings with low median node; segment 8 with long, curved median spine on axial ring, recurved forward to almost meet with occipital spine when thorax performs a concave curvature. Surface of cuticle smooth.

Description. Cranidium with a length-to-width ratio (occipital spine and genal spines excluded) of $68-73 \%$ in the studied specimens. Glabella (exclusive of occipital spine) of 78-83\% cephalic length in the studied specimens, maximum width across L 1 of $35-38 \%$ maximum cranidial width across mid-length of palpebral lobes; glabellar length slightly affected by the grade of dorsoventral compaction that affects the convexity of the pre-glabellar part of the cranidium. Glabella mostly faintly tapering forward from occipital furrow, with width across frontal lobe ca. $85 \%$ width across L1, but distinctly tapering in two of the studied specimens (Fig. 9k); gently convex in transverse section, but without the typical almost bar-like elevation seen in most species of Kingaspidoides; faint sagittal crest-line visible on internal moulds of three of the studied specimens (Fig. 9o); frontal lobe with faint anterolateral corners, anterior margin in dorsal view with almost even curvature, but occasionally with faint median kink; four pairs of faint lateral glabellar furrows, S1-S3 recognizable as shallow depressions on internal moulds, all disconnected medially. S4 short, mostly obsolescent. Occipital furrow moderately broad (sag. and exsag.), almost straight, clearly shallow on the exterior of the cuticle. Occipital ring moderately broad (sag.), exclusive of occipital spine of ca. $15 \%$ of cephalic length, extended into a long terminal spine; this spine is directed dorsally with a distinct concave curvature so that the tip points more or less exactly upright.

Axial furrows relatively broad and shallow, poorly defined from fixigenae.

Fixigena posterior to eye ridge gently convex in transverse section, but genal sector generally sloping slightly ventrally in abaxial direction; near axial furrow of ca. $45 \%$ cephalic length (exsag.; occipital spine excluded), transverse width across mid-length of the palpebral lobes of ca. $65 \%$ maximum glabellar width and only $22-24 \%$ maximum cranidial width.

Palpebral lobe variably developed, but without considerable reduction in length during growth, relatively short for a species of Kingaspidoides, in adult individuals exsag. of 23-26\% cranidial length (occipital spine excluded), width in the order of 6-8\% cranidial width across centres of palpebral 

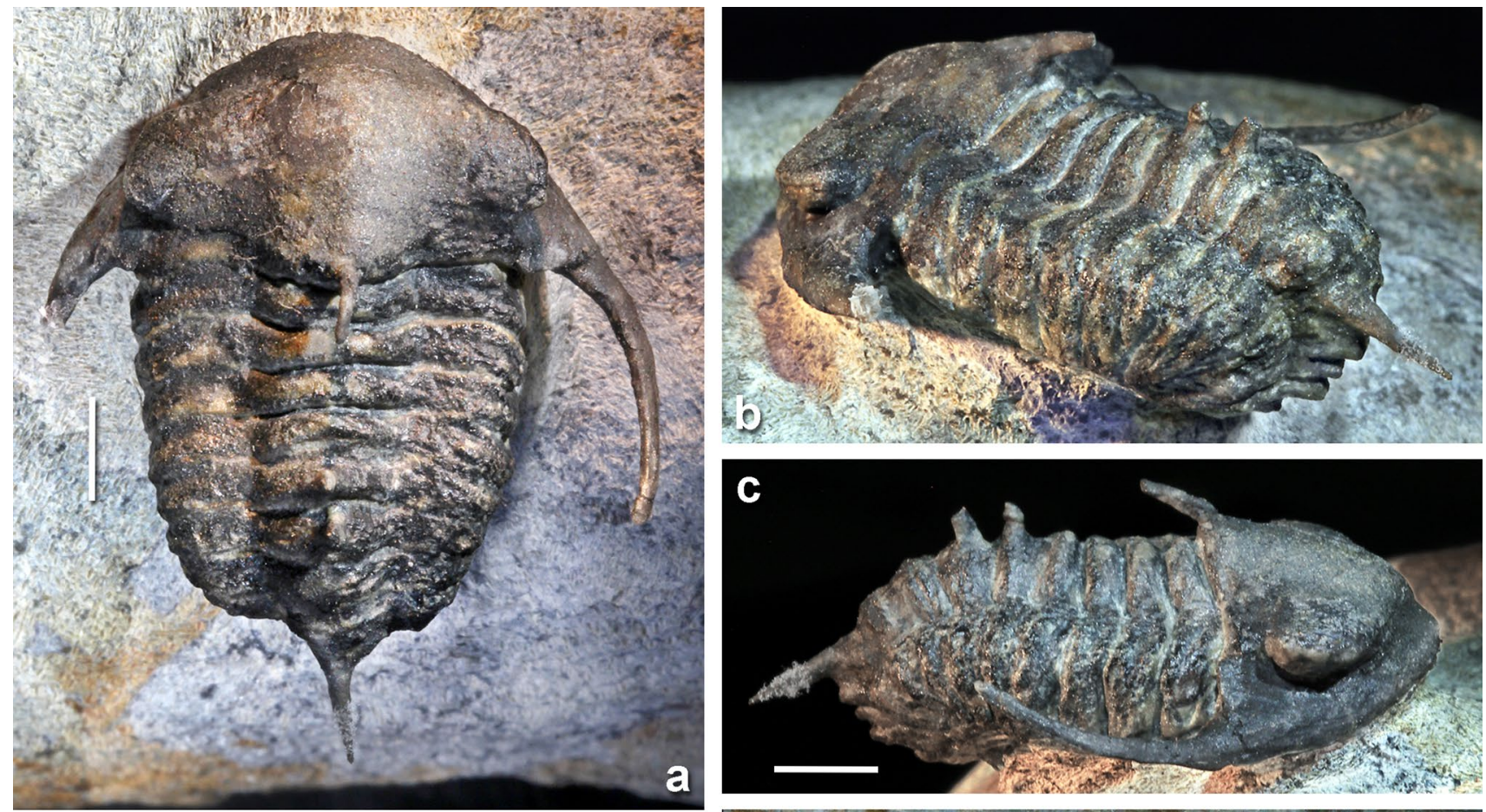

a
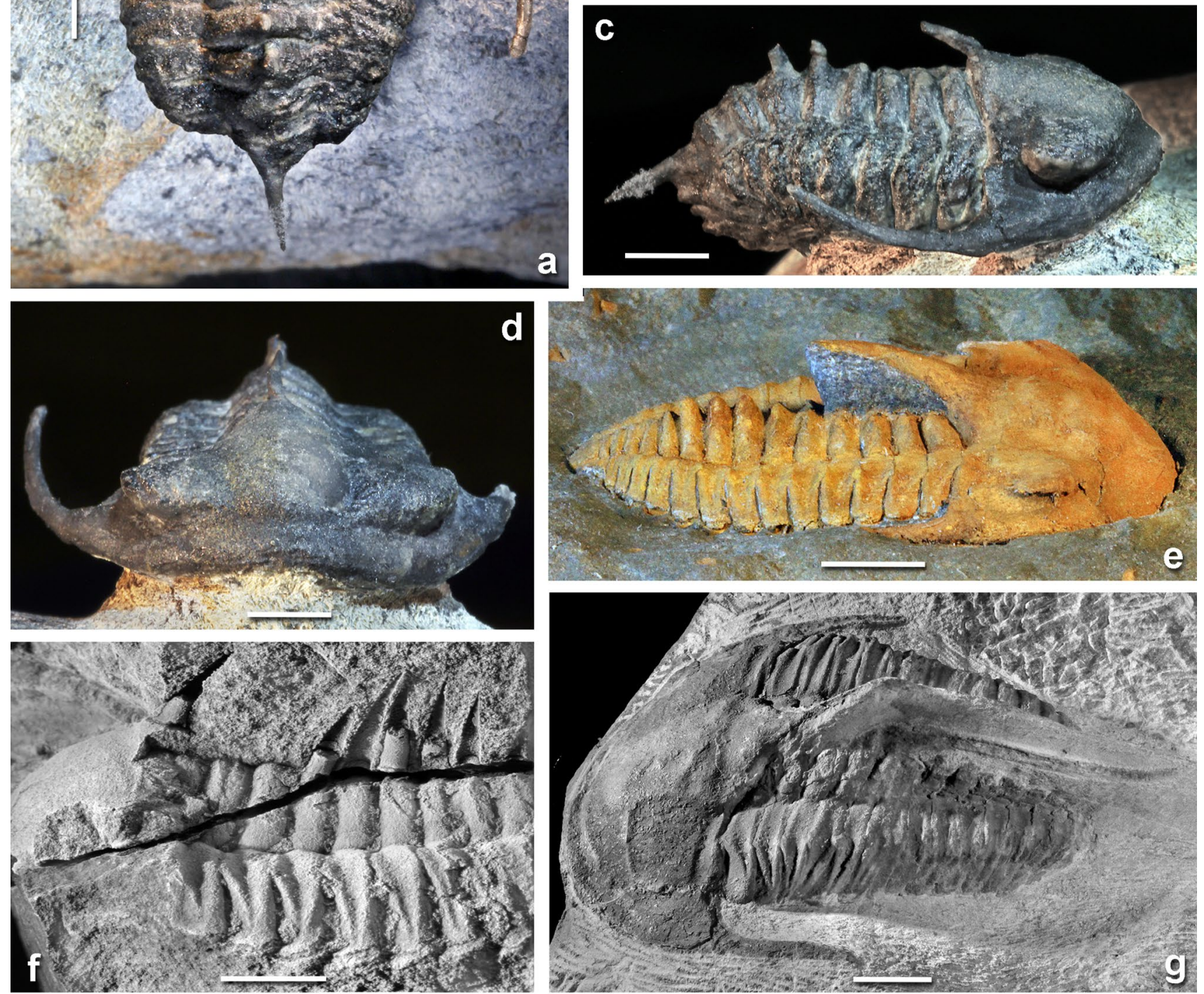

lobes; weakly convex in transverse section on the exterior of the cuticle, gently convex (tr.) on internal moulds, with slightly crescentic shape, distinctly curved along suture toward visual surface, less curved toward palpebral furrow, with anterior end at approximately the level of the anterior part of L3, in a faintly more adaxial position than posterior end; posterior end approximately at level of L2; better defined and narrower on internal moulds; considerably elevated above librigenal platform (Fig. 9j). Palpebral furrow a shallow depression, poorly defined on the exterior of the cuticle, relatively distinct on internal moulds; extends on internal moulds anteroproximally into a shallow and poorly 
४Fig. 6 a-d Kingaspidoides sp. C, BOM 2230, nearly complete dorsal exoskeleton with enrolled posterior part of the thoracopygon, dorsal, oblique posterolateral, lateral and anterior views; occipital ring with moderately large, slightly deformed occipital spine, thoracic segments 4-6 with axial spines increasing in length, thoracic segment 9 with macrospine on axial ring; probably from Ornamentaspis frequens Biozone, Jbel Wawrmast Formation, upper part of Bréche à Micmacca Member, Anti-Atlas, Morocco, most probably from Jbel Ougnate region, possibly from strata with Kingaspidoides spinirecurvatus. Scale bars $5 \mathrm{~mm}$. e Cambrosaurura robusta Geyer in Cederström et al., Collection Devoille, DEV C 15.2b, lateral view of dorsal exoskeleton illustrating robust, rearwardly directed occipital spine and bulbous nodes of different sizes on axial rings. Jbel Wawrmast Formation, Bréche à Micmacca Member, from unknown locality of the Jbel Ougnate region, eastern Anti-Atlas, Morocco. Scale bar $5 \mathrm{~mm}$. $\mathbf{f}$ Kingaspidoides sp. D, SMF 96569a, partial dorsal exoskeleton, lateral view; occipital ring with relatively long occipital spine, thoracic segments 3-8 with strong, dorsally directed axial spines increasing and decreasing in length, longest on segment 6; from Ornamentaspis frequens Biozone, Tannenknock Formation, Wildenstein Member, locality W8 north of Wildenstein, Franconian Forest, Germany. Scale bar $5 \mathrm{~mm}$. g Kingaspis sp., undescribed new species, Collection Gérard Barbe, CGB T. 41, incomplete dorsal exoskeleton, oblique lateral view showing slender, long, rearwardly directed occipital spine and extremely long and rearwardly directed axial spine on thoracic segment 6. Jbel Wawrmast Formation, Bréche à Micmacca Member, from unknown locality of the Jbel Ougnate region, eastern Anti-Atlas, Morocco. Scale bar $5 \mathrm{~mm}$

defined furrow that separates the eye ridge from the fixigena posterior to it. Eye ridge a low, obliquely transverse and weakly curved torus, poorly marked on the exterior of the cuticle, separated from palpebral lobe by a constriction and a weakly defined depression.

Anterior area of the cranidium uniformly convex on the exterior of the cuticle, with anterior border generally not defined or obsolescent both on the exterior and interior of the cuticle. Anterior area of ca. $20 \%$ cephalic length (occipital spine excluded), gently convex, moderately well demarcated from glabellar front on internal moulds, but separated only by changes in convexity on the exterior of the cuticle; grades laterally into preocular areas without any recognisable distinction. Anterior border on the sagittal line poorly marked in most individuals, of only ca. 5\% cephalic length in dorsal view, of nearly equal breadth (sag., exsag.) throughout, distinctly narrower (sag., exsag.) than pre-glabellar field.

Posterior border faintly defined on the exterior of the cuticle, moderately wide, relatively narrow close to the axial furrow and growing in width abaxially to a moderately broad (exsag.) lobe for most of its extension on internal moulds, slightly to moderately convex, transverse to the length axis in the proximal and median part, its course swinging slightly anteriorly in the distal part, with a small process serving for articulation with first thoracic segment posterior to palpebral furrow. Posterior border furrow a shallow, moderately broad (exsag.) groove.
Anterior branches of the facial suture are difficult to recognize in most specimens, weakly divergent from anterior ends of ocular suture, straight for most of its course, with slight adaxial curvature at approximately the supposed position of the anterior border. Posterior branches are equally difficult to recognize, moderately divergent, comparatively weakly curved.

Librigena moderately wide (tr.), with a moderately long to long, relatively strong, genal spine of roughly equal length of the anterior part of the librigena. Genal spine weakly curved, with a moderately broad base that defines a gentle curvature from the posterior margin to the adaxial rim of the genal spine. Lateral margin gently and evenly curved, at most with a faint bend at the base of the genal spine. Palpebral section of the suture moderately large, corresponding to an eye length of ca. one-quarter cephalic length. Librigenal field fairly narrow in dorsal view, slightly convex, slopes gently downward from the palpebral section toward the weakly defined border furrow. Lateral border slightly convex in transverse profile, subequal to the librigenal field's transverse width.

Hypostome and rostral plate unknown.

Thorax of 14 segments (possibly 15 segments in two of the studied specimens) in adult individuals. Axial rings of segment 3-7 and 9-14 of more or less uniform shape (sag. and exsag.), length and width reduced progressively posteriorly to less than half maximum width across segment 3 , whereas the reduction in sagittal and exsagittal directions are less affected by allometric growth. Transverse width of average axial ring ca. 35\% of overall width of the segment, growing slightly in relative width to ca. $45 \%$ in the posterior segments. Moderately broad (sag. and exsag.) articulating furrow with distal apodemal pit. Surface of axial ring gently convex in sagittal and exsagittal profile. Each axial ring with an (usually low) axial node, which apparently tends to be better developed and more prominent in the mid-thoracic segments. Greatest overall width (tr.) of thorax at segments $1-3$, decreasing in width (tr.) rearward, with slightly but progressively backward directed distal parts of pleurae, particularly posterior to segment 10 . Pleural furrows moderately broad to broad (exsag.), forming furrows of narrow lenticular outline slightly oblique to transverse axis, which fade a short distance from pleural tips (e.g., Fig. 9k). Pleural tips blunt, somewhat obliquely subtruncate, but with minute, slightly posterolaterally directed spine or thorn. In anterior view, the pleurae have a distinct geniculation adaxial to the transverse mid-length, which corresponds to the articulation of the adjacent segments by means of fulcral points. As a result, the anterior flanks of the distant pleural portions have an almost flat, anteriorly tilted articulating facet, whereas the posterior margin of the distal pleura turns slightly forward to allow a limited overlap of adjacent segments during inclination of the segments (Fig. 9k, m). 
Fig. 7 Geological map of the Jbel Ougnate region, eastern Anti-Atlas, based on the official Todrha-Ma'der map sheet of the Service Géologique du Maroc, Rabat, with location of the Kingaspidoides spinirecurvatus sp. nov. sampling localities near Tizi n'Tfarkhin and Tizi n'Izem and other renowned fossil localities of Cambrian trilobites in the region. Insert shows lithostratigraphical and biostratigraphical units for the relevant stratigraphic interval. Cambrian Stage 4-Wuliuan boundary not precisely correlatable into West Gondwana

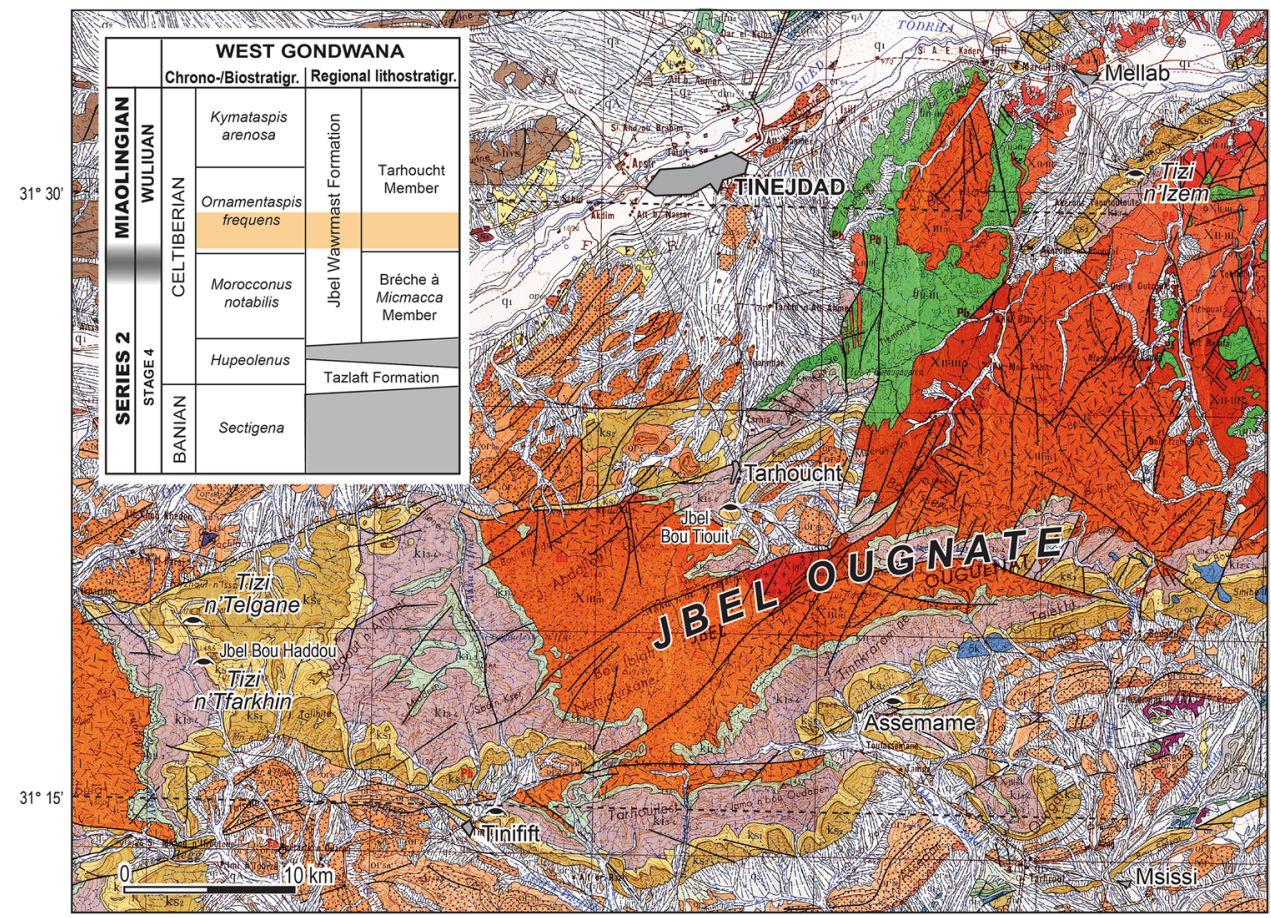

The first/anterior thoracic segment differs in having an axial ring with an anterior margin that swings backward to allow a distinctive dorsal flexure of the cephalon against the thorax. Its pleurae are straight in the proximal sector, but show a well-developed fulcral point to fit into the socket of the cephalon's posterior border; distal part of pleura reduced in size, with a somewhat backward-directed anterior margin and an obliquely ventrally deflected articulating facet. This configuration is repeated in a less distinct manner in the second thoracic segment.

Segment 8 with a slightly broadened axial ring, which extends into a prominent, large, conspicuously curved spine. This spine is posterodorsally directed from its origin but strongly curved in lateral view so that its tip is directed anterodorsally (Fig. 9m).

Pygidium incompletely known, only preserved in two specimens (Fig. 9i, n), but clearly of volucent morphology, with segments having a similar morphology as the posterior thoracic segments; considerably convex in sagittal and transverse profile. Axis clearly defined, tapering rearward, convex in transverse profile, consisting of at least five axial rings, apparently reaching to posterior margin. Pleural areas similar in morphology to thoracic segments, with well-developed pleural and interpleural furrows, but without lateral border (Fig. 9n).

Surface of cuticle smooth, finely punctate in places.
Dimensions. Fully grown cranidia of Kingaspidoides spinirecurvatus are between 25 and $40 \mathrm{~mm}$ long (holotype: $32.8 \mathrm{~mm}$ ), with $20-32 \mathrm{~mm}$ width between the tips of the genal spines ( $26.3 \mathrm{~mm}$ in the holotype). The width between the ocular sutures at the palpebral lobe is $17.4 \mathrm{~mm}$ in the holotype. The length of the thoracopygidial part of the exoskeleton is usually between 25 and $30 \mathrm{~mm}(22.3 \mathrm{~mm}$ in the holotype).

Comparison. Kingaspidoides spinirecurvatus is easily distinguished from all other species of the genus Kingaspidoides by its two long occipital and axial spines. The species is typical for the genus Kingaspidoides in having fixigenalpalpebral units sloping ventrally toward the suture with little difference in convexity between the interior and exterior surfaces of the exoskeletal cuticle (other than in the species of Ornamentaspis), in a fairly uniformly vaulted and ventrally deflected anterior area, and in having a glabella with subparallel sides. The most similar cranidium can be seen in large individuals of Kingaspidoides destombesi (Geyer, 1990), which is distinguished by a simple, moderately long and more or less straight occipital spine and a distinct Bertillon pattern on most of the cranidium.

Kingaspidoides spinirecurvatus also has relatively strongly developed genal spines that fit into the spine apparatus discussed above. The cuticular surface is finely punctate (Fig. 8d) and certainly lacks any distinct granules or Bertillon patterns that occur in a number of species from 

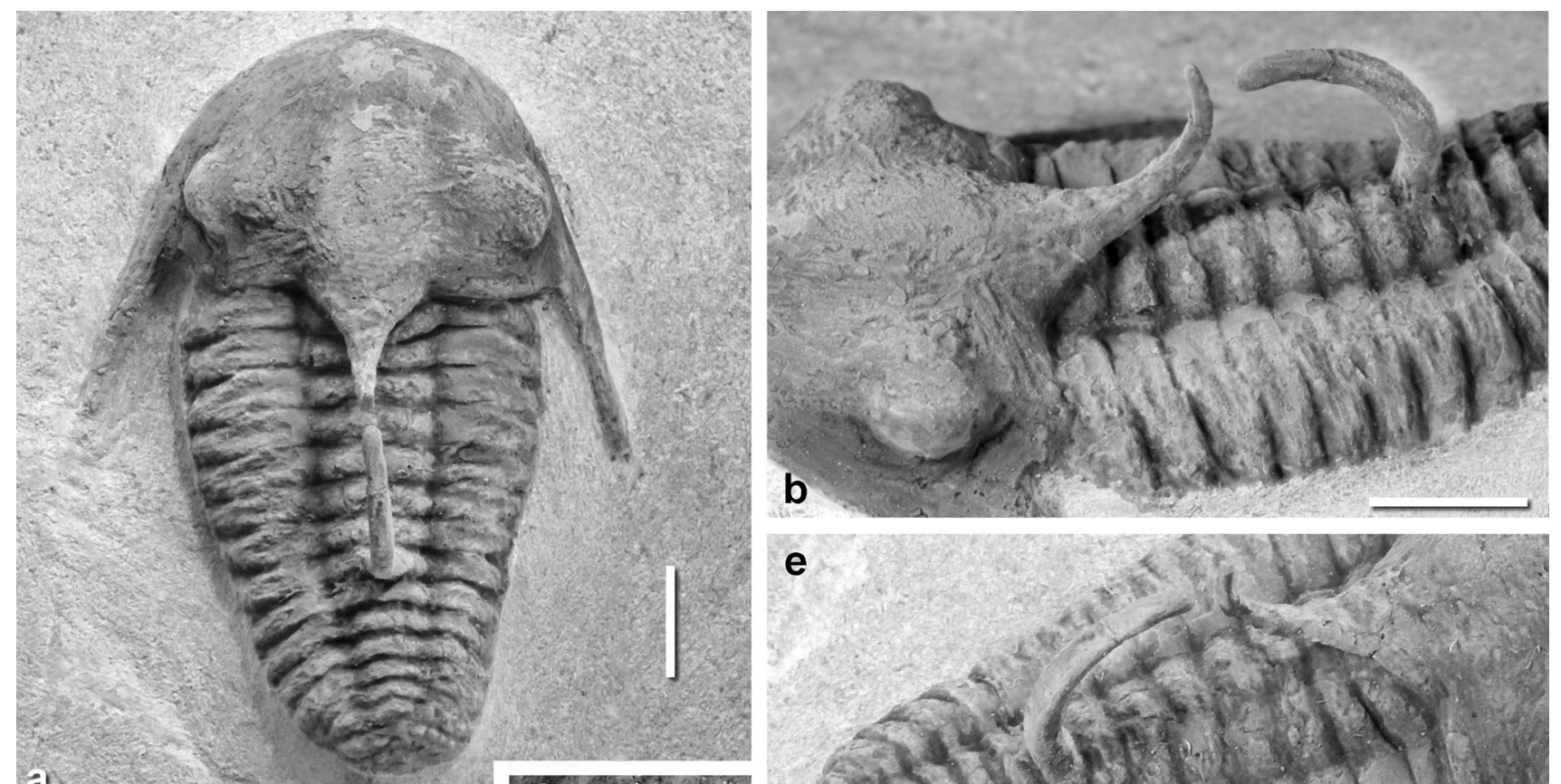

a)
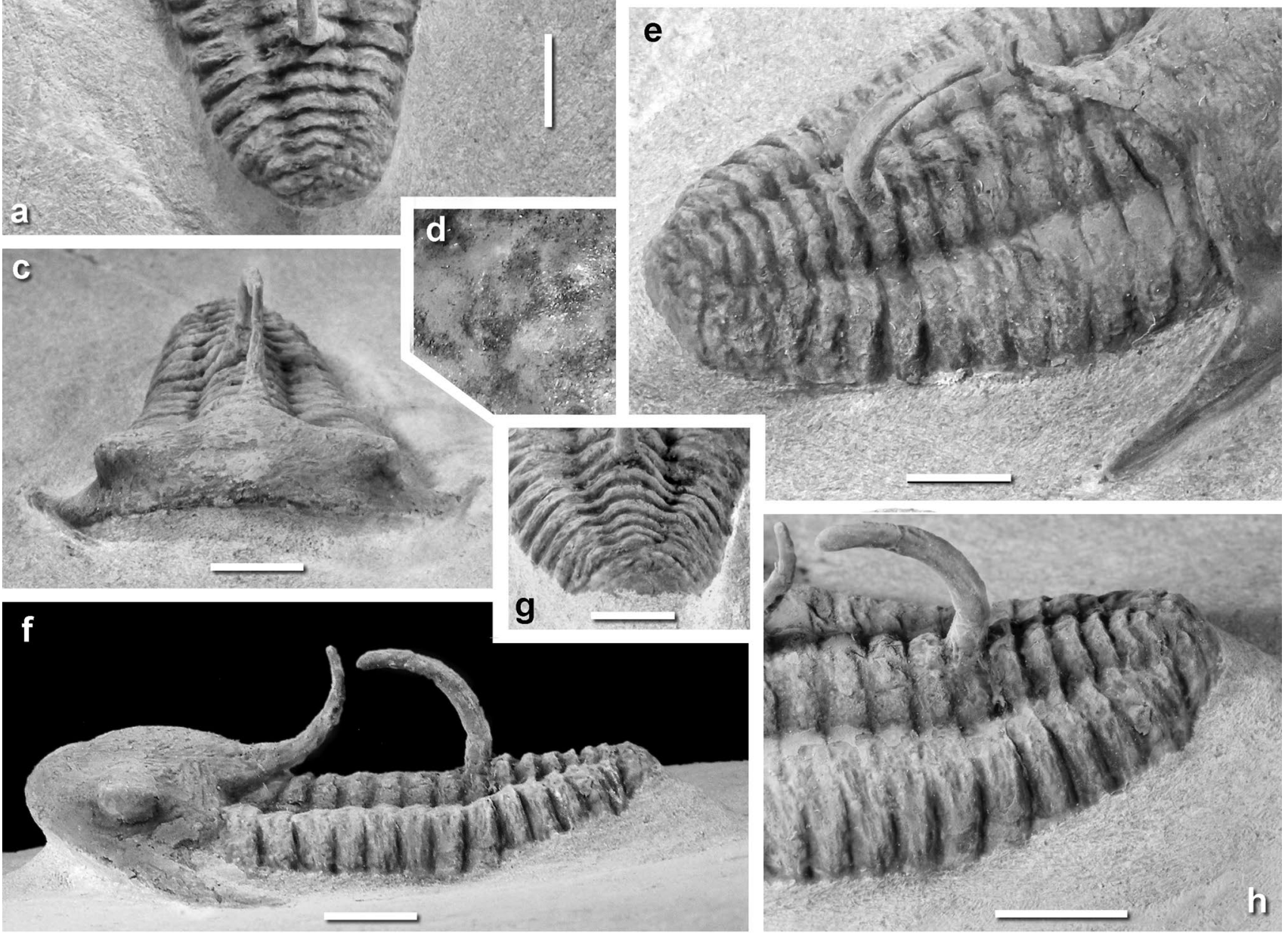

Fig. 8 Kingaspidoides spinirecurvatus sp. nov. a-c, e-h Holotype, FG 688, complete exoskeleton with slightly concave flexure; a dorsal view; $\mathbf{b}$ oblique lateral view with spine configuration and comparatively well-defined palpebral lobes; $\mathbf{c}$ anterior view; $\mathbf{e}, \mathbf{f}$ dorsolateral and lateral views illustrating fulcral points and well developed facets on thoracic pleura; $\mathbf{g}$ oblique posterior view showing posterior part of the thorax and damaged, slightly ventrally inclined pygidium; $\mathbf{h}$ oblique lateral view of middle and posterior part of the thorax and pygidium with slightly broadened axial ring of thoracic segment 8 and subequal curvature of axial spine. From Ornamentaspis frequens Biozone, Jbel Wawrmast Formation, upper part of Bréche à Micmacca Member, sample locality near Tizi n’Tfarkhin, Jbel Ougnate region, eastern Anti-Atlas, Morocco. d Paratype, Collection Gérard Barbe, CGB T. 41, detail of glabella showing finely punctate surface and lateral glabellar furrows, oblique anterolateral view; from unknown locality, Jbel Ougnate region, eastern Anti-Atlas, Morocco. All scale bars $5 \mathrm{~mm}$ 

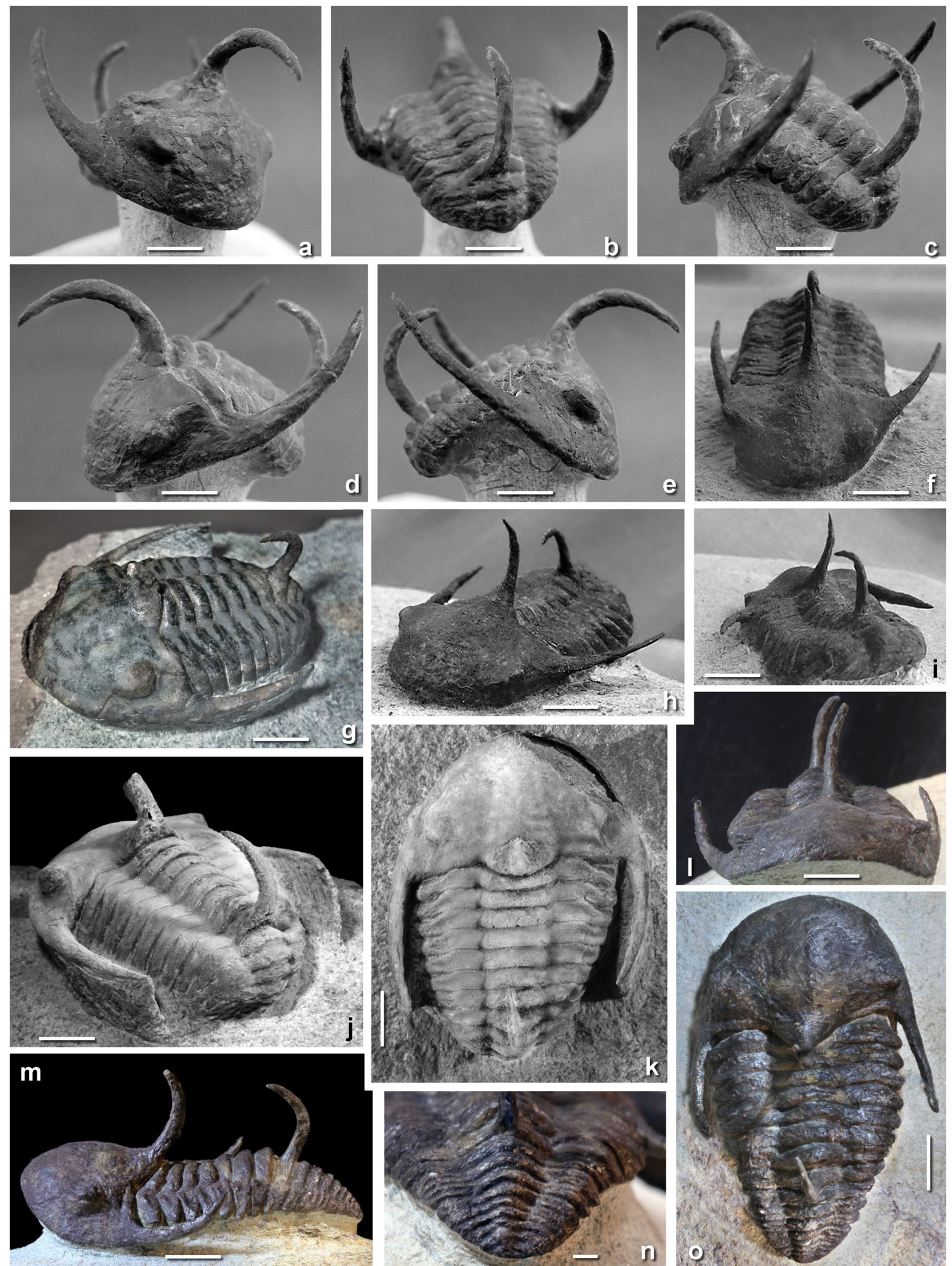
४Fig. 9 Kingaspidoides spinirecurvatus sp. nov. a-e Slightly enrolled dorsal carapace, different views illustrating the spatial arrangement of genal spines, occipital spine and axial spine on thoracic segment 8 . $\mathbf{f}, \mathbf{h}, \mathbf{i}$ Dorsal carapace with strongly inclined posterior part of thorax and attached pygidium, different views to illustrate the direction of macrospines. All specimens from Ornamentaspis frequens Biozone, Jbel Wawrmast Formation, upper part of Bréche à Micmacca Member, sample locality near Tizi n'Tfarkhin, Jbel Ougnate region, eastern Anti-Atlas, Morocco. g, j, k Collection Gérard Barbe, CGB T. 41, dorsal carapace with inclined posterior part of thorax; $\mathbf{g}$ oblique anterolateral view of uncoated specimen; $\mathbf{j}$ posterolateral view showing eyes and palpebral lobes elevated above librigenal platform and considerable gap between axial rings of thoracic segments 8 and 9, specimen coated with ammonium chloride; $\mathbf{k}$ dorsal view of specimen with considerably tapering glabella and shallow lateral glabellar furrows, specimen coated with ammonium chloride; from unknown locality, Jbel Ougnate region, eastern Anti-Atlas, Morocco. 1-o Paratype, Collection Devoille, DEV C 15.2b, outstretched dorsal exoskeleton with slight double curvature; $\mathbf{I}$ anterior view; $\mathbf{m}$ lateral view showing differences in the sagittal width of the axial rings and facets of pleurae; $\mathbf{n}$ posterior view showing distinctly segmented pygidium without lateral and posterior borders; o dorsal view; from unknown locality, Jbel Ougnate region, eastern Anti-Atlas, Morocco. All scale bars $5 \mathrm{~mm}$ except for $n(=1 \mathrm{~mm})$

West Gondwana, but examination of perfectly preserved specimens is needed to further discriminate the precise surface design.

History of discovery and commercial use. Kingaspidoides spinirecurvatus sp. nov. is hitherto known from a number of specimens on the fossil market, sold under various names, mostly as "Kingaspis sp." or "Kingaspidoides sp.". Three specimens were recognized in 1988 from small fragments of cranidia from the Tizi n'Izem locality of the Jbel Ougnate region, eastern Anti-Atlas (sample horizon TNI-N2 of Geyer 1990) that showed the unique occipital spine with its anterior curvature, but excluded from a formal description in Geyer (1990) because of expected subsequent better preserved and more conclusive material. Another fragment of a specimen was found from the scree unequivocally coming from the upper part of the Bréche à Micmacca Member or the lowest Tarhoucht Member of the Bou Tiouit section near Tarhoucht, thus roughly coeval with the material from the Tizi n'Izem section. Unfortunately, these specimens have been lost during relocation of samples.

The species is easily recognized by the two recurved spines on the occipital ring and thoracic segment 8 , which unequivocally distinguish it from all other species of the genus Kingaspidoides. This configuration of the spines is also unknown from all species of the closely related genera, such as Ornamentaspis, Kymataspis, Ellipsostrenua, or Cambrosaurura.

Commercial exploitation of the species started in the 1990s, and a number of specimens were offered and sold on the fossil market. However, the species remained relatively rare, and most specimens were damaged, incomplete and/or partly faked. Commercially traded specimens are almost exclusively prepared mechanically from relatively thin, partly nodular limestone beds by means of chisels, needles and vibrotools, which cause considerable scratching of the shell and split-off particles. The conspicuous occipital and axial spines break off during preparation and are glued to the rest of the carapace at the end of the preparation process, sometimes replaced by spines that originate from other specimens, even other trilobite species or other materials. In a number of cases, the spines are mounted in a wrong direction on the rest of the exoskeleton so that the occipital spine or the axial spine appears to curve rearward.

Preservation. The specimens known of Kingaspidoides spinirecurvatus sp. nov. are all preserved in carbonate horizons of variable lithology, but generally slightly argillaceous or with considerable clay content. The cuticle is preserved as a black phosphatized coat. This preservation is typical for skeletal fossils from the uppermost part of the Bréche à Micmacca Member and the lower part of the Tarhoucht Member of the Jbel Wawrmast Formation in a number of sections in the eastern Anti-Atlas, and differs considerably from the normal preservation of skeletal fossils of the Jbel Wawrmast Formation, which are generally preserved as orange to brownish coatings resulting from the weathered calcareous substance of the shells and cuticles in the yellowish-green fine-grained sandstones of the lower and middle parts of the Bréche à Micmacca Member.

Typical carbonate beds from which the specimens of Kingaspidoides spinirecurvatus are recovered are slightly nodular and contain a plethora of trilobite and brachiopod sclerites, with an unusually high number of articulated specimens. The limited, but occasionally evident fracturing of these sclerites indicates deposition under high energy conditions, but with only a very limited transport distance. Nevertheless, these conditions appear to be limited to only a few localities, with fracturing of fossil shells and sclerites being a general condition in nearby locations of the same beds.

Acknowledgements Open Access funding provided by Projekt DEAL. The preparation of the manuscript was made possible by research grant GE 549/22-1 of the Deutsche Forschungsgemeinschaft (DFG) to G.G. The late Patrick and Martine Bommel (Bize-Minervois, France), Gérard Barbe (Champillon, France), and Géorges and Joëlle Devoille (Pierrefeu-du-Var, France) generously provided access to the specimens in their collections and hospitality for this study. Further Moroccan specimens other than those of Kingaspidoides spinirecurvatus have been collected by the senior author during various field trips mostly supported by the DFG. We thank the Moroccan fossil excavators and preparators Youssef Igerna, Brahim Ben Moula, and Oumouhou Mhammed for information on the localities, photos of the preparation process and details about the discovery and preparation history. Access to two additional specimens was provided by the Naturmuseum Senckenberg, Frankfurt am Main. Furthermore, we appreciate locality and 
specimen information by Brahim Tahiri (Tahiri Museum, Ksar Ksir Siffa, Erfoud) and John Adamek (Fossil Mall), and additional hints on specimens by Ulrich Lemke (Wetter, Germany) and Matthias Svojtka (Vienna, Austria) and locality information by Tony Vincent (Aberdeen, UK). Tony Vincent also improved the language. Brian Chatterton (Edmonton, Canada) provided photos of Devonian trilobites from the publication of Chatterton et al. (2006), Allart Van Viersen (Maastricht, The Netherlands) photos of Cyphaspis from Van Viersen and Holland (2016), which is gratefully acknowledged. Palaeontologica Canadiana and Geologica Belgica kindly permitted reproduction of photos from the mentioned publications.

Open Access This article is licensed under a Creative Commons Attribution 4.0 International License, which permits use, sharing, adaptation, distribution and reproduction in any medium or format, as long as you give appropriate credit to the original author(s) and the source, provide a link to the Creative Commons licence, and indicate if changes were made. The images or other third party material in this article are included in the article's Creative Commons licence, unless indicated otherwise in a credit line to the material. If material is not included in the article's Creative Commons licence and your intended use is not permitted by statutory regulation or exceeds the permitted use, you will need to obtain permission directly from the copyright holder. To view a copy of this licence, visit http://creativecommons.org/licenses/by/4.0/.

\section{References}

Barrande, J. 1852. Système Silurien du Centre de la Bohême. 1ère Partie. Recherche paléontologiques. Crustacés, Trilobites. Vol. 1, 1-935. Prague, Paris.

Bergström, J. 1983. Organization, life, and systematics of trilobites. Fossils and Strata 2: 1-69.

Cederström, P., G. Geyer, P. Ahlberg, C.H. Nilsson, and J. Ahlgren. under review. Ellipsocephalid trilobites from Cambrian Series 2 and Stage 4 in Scania, Sweden: taxonomy, morphological plasticity and biostratigraphic significance. Fossils and Strata.

Chatterton, B.D., R.A. Fortey, K.D. Brett, S.L. Gibb, and R.C. McKellar. 2006. Trilobites from the upper Lower to Middle Devonian Timrhanrhart Formation, Jbel Gara el Zguilma, southern Morocco. Palaeontographica Canadiana 25: 1-177.

Devaere, L., S. Clausen, and Álvaro, J. J. 2014. Stratigraphic overview of the Ediacaran and Cambrian from the Anti-Atlas, Morocco. International meeting, Ouarzazate, Morocco, 15-24 September 2014, 1-85. Lille: University of Lille.

Geyer, G. 1989. Late Precambrian to early Middle Cambrian lithostratigraphy of southern Morocco. Beringeria 1: 115-143.

Geyer, G. 1990. Die marokkanischen Ellipsocephalidae (Trilobita: Redlichiida). Beringeria 3: 1-363.

Geyer, G. 1993. The giant Cambrian trilobites of Morocco. Beringeria 8: 71-107.

Geyer, G. 2017. Trilobites of the Galgenberg Member (Tannenknock Formation), middle Cambrian Stage 5, Franconian Forest, Germany: a paradigmatic lowermost middle Cambrian West Gondwanan fauna. PalZ. Paläontologische Zeitschrift 91: 5-70.

Geyer, G., and E. Landing. 2006. Latest Ediacaran and Cambrian of the Moroccan Atlas regions. In Ediacaran-Cambrian depositional environments and stratigraphy of the western Atlas regions. eds. G. Geyer, and E. Landing. Beringeria Special Issue 6: 7-46. (= Infracambrian/Early Palaeozoic Field Guide Series 1, UCL Maghreb Petroleum Research Group).

Geyer, G., and T. Vincent. 2015. The Paradoxides puzzle resolved: the appearance of the oldest paradoxidines and its bearing on the
Cambrian Series 3 lower boundary. Paläontologische Zeitschrift 89: 335-398.

Geyer, G., E. Landing, and W. Heldmaier. 1995. Faunas and depositional environments of the Cambrian of the Moroccan Atlas region. In MOROCCO '95-the Lower-Middle Cambrian standard of western Gondwana., eds. G. Geyer, and E. Landing. Beringeria Special Issue 2: 47-119.

Geyer, G., J. Nowicki, A. Żylińska, and E. Landing. 2019. Comment on: Álvaro, J. J., Esteve, J. \& Zamora, S. Morphological assessment of the earliest paradoxidid trilobites (Cambrian Series 3) from Morocco and Spain [Geological Magazine]. Geological Magazine. https://doi.org/10.1017/S0016756818000961.

Heldmaier, W. 1998. The Lower-Middle Cambrian transition along the northwestern margin of Gondwana (Anti-Atlas and Atlas ranges, Morocco). Unpublished Ph.D. dissertation, Fakultät für Geowissenschaften, Universität Würzburg. Würzburg.

Hupé, P. 1953. Contribution à l'étude du Cambrien inférieur et du Précambrien III de l'Anti-Atlas marocain. Notes et Mémoirs de la Service Géologique du Maroc 103: 1-402.

Kautsky, F. 1945. Die unterkambrische Fauna vom Aistjakk in Lapland. Geologiska Föreningens $i$ Stockholm Förhandlingar 67: 129-211.

Kobayashi, T. 1935. The Cambro-Ordovician formations and faunas of South Chosen. Paleontology. Part III. Cambrian faunas of South Chosen with a special study on the Cambrian trilobite genera and families. Journal of the Faculty of Science, Imperial University of Tokyo, Sect. II, Geology, Mineralogy, Geography, Seismology IV: 49-344.

Linnarsson, G. 1883. De undre Paradoxideslagren vid Andrarum. Sveriges geologiska Undersökning (C: Avhandlingar och uppsatser) 54: $1-48$.

Matthew, G.F. 1887. Illustrations of the fauna of the St. John Group. No. IV.- on the smaller-eyed trilobites of Division 1, with a few remarks on the species of the higher divisions of the group. Canadian Record of Science 2: 357-363.

Morzadec, P. 2001. Les trilobites Asteropyginae du Dévonien de l'Anti Atlas (Maroc). Palaeontographica (A: Paläozoologie, Stratigraphie) 262: 53-85.

Orłowski, S. 1985. New data on the Middle Cambrian trilobites and stratigraphy in the Holy Cross Mts. Acta Geologica Polonica 35: 251-263.

Richter, R. 1932. Crustacea (Paläontologie). In Handwörterbuch der Naturwissenschaften, 2nd ed., 840-863. Jena: G. Fischer.

Schlotheim, E.F. 1823. Nachträge zur Petrefactenkunde. Zweite Abteilung, 1-114. Gotha: Beckersche Buchhandlung.

Seilacher, A. 1959. Vom Leben der Trilobiten. Die Naturwissenschaften 46: 389-393.

Šnajdr, M. 1957. O nových trilobitech z českého kambria. Veštník Ústředního ústavu geologického 32: 235-244.

Van Viersen, A.P., and D. Holland. 2016. Morphological trends and new species of Cyphaspis (Trilobita, Otarioninae) in the Devonian of Morocco, Turkey, Germany and Belgium. Geologica Belgica 19: 251-271.

Walch, J.E.I. 1771. Die Naturgeschichte der Versteinerungen. Dritter Theil. Zur Erläuterung der Knorrischen Sammlung von Merkwürdigkeiten der Natur, viii + 1-235. Nürnberg: P.J. Felßecker.

Wurm, A. 1925. Über ein Vorkommen von Mittelcambrium (Paradoxidesschichten) im bayrischen Frankenwald bei Wildenstein südlich Presseck. Neues Jahrbuch für Mineralogie, Geologie und Paläontologie (B: Geologie und Paläontologie), Beilagen-Band 52: 71-93.

Zenker, J.C. 1833. Beiträge zur Naturgeschichte der Urwelt. Organische Reste (Petrefacten) aus der Altenburger Braunkohlen-Formation, dem Blankenburger Quadersandstein, jenaischen bunten Sandstein und böhmischen Übergangsgebirge, 1-67. Jena. 